International Journal of Social Learning

December 2021, Vol. 2 (1), 16-38

e-ISSN 2774-4426 and p-ISSN 2774-8359

DOI: https://doi.org/10.47134/ijsl.v2i1.40

\title{
Differences in Reading by the Economic Status of Texas Grade 4 Boys and Girls in Special Education: A Multiyear Statewide Investigation
}

\author{
Matthew M. Pariseau ${ }^{1}$, John R. Slate ${ }^{2 *}$, and Frederick C. Lunenburg ${ }^{3}$ \\ ${ }^{1}$ Spring Independent School District, United States of America \\ ${ }^{2,3}$ Sam Houston State University, United States of America \\ *e-mail: jrs051@shsu.edu
}

\begin{abstract}
In this investigation, the degree to which the economic status (i.e., Not Economically Disadvantaged, Economically Disadvantaged) of Texas Grade 4 boys and girls in special education was related to their reading performance was addressed. Archival data from the Texas Education Agency Public Education Information Management System were analyzed for 2014-2015, 2015-2016, 2016-2017, and 2017-2018 school years on the Texas state-mandated reading assessment for Grade 4 students. Inferential statistical analyses, conducted separately for boys and girls in special education, revealed that boys and girls in poverty had statistically significantly lower reading test scores than boys and girls who were not in poverty. Results in all four school years were consistent with the existing research literature in that poverty negatively affects reading performance. Implications for policy and practice were provided, as well as recommendations for future research.
\end{abstract}

Keywords:

Special Education; Reading Achievement; Economic Status; Gender; Disabilities.

\begin{abstract}
ABSTRAK
Dalam penyelidikan ini, sejauh mana status ekonomi (yaitu, Tidak Tertinggal Secara Ekonomi, Tertinggal Secara Ekonomi) anak laki-laki dan perempuan Kelas 4 Texas dalam pendidikan khusus terkait dengan kinerja membaca mereka dibahas. Data arsip dari Sistem Manajemen Informasi Pendidikan Umum Badan Pendidikan Texas dianalisis untuk tahun ajaran 2014-2015, 2015-2016, 2016-2017, dan 2017-2018 pada penilaian membaca yang diamanatkan negara bagian Texas untuk siswa Kelas 4.
\end{abstract}


Analisis statistik inferensial, yang dilakukan secara terpisah untuk anak laki-laki dan perempuan dalam pendidikan khusus, mengungkapkan bahwa anak laki-laki dan perempuan dalam kemiskinan secara statistik memiliki nilai tes membaca yang lebih rendah daripada anak laki-laki dan perempuan yang tidak miskin. Hasil di keempat tahun sekolah konsisten dengan literatur penelitian yang ada bahwa kemiskinan berdampak negatif terhadap kinerja membaca. Implikasi untuk kebijakan dan untuk praktek disediakan, serta rekomendasi untuk penelitian masa depan.

\section{Kata Kunci:}

Pendidikan Luar Biasa, Prestasi Membaca, Status Ekonomi, Gender, Disabilitas.

\section{Introduction}

Of the children in the State of Texas, $24 \%$ of them are in poverty, a rate that is $5 \%$ higher than the national average (National Center for Children in Poverty, 2019). Even more alarming is the percentage of students who are in poverty (i.e., 59\% of elementary school students) who attend Texas public schools (National Center for Education Statistics, 2019b). Similarly, high numbers of students in poverty exist in the secondary level, $58 \%$ of middle school students (Wright \& Slate, 2015 ) and $43 \%$ of high school students (Lee \& Slate, 2014). The sheer number of students in poverty is staggering with over 7,000,000 children experiencing the negative effects of poverty (National Center for Children in Poverty, 2019).

In a study sponsored by the Annie E. Casey Foundation, 4,000 students who did not read at grade level by Grade 3 were determined to be four times more likely to drop out of school than their peers who were reading at grade level (Hernandez, 2012). When poor reader status was combined with living in poverty, the probability of them dropping out exponentially increased, thus creating a "double jeopardy" that negatively influenced high school graduation rates (p. 4). Of the children who are living in poverty, it is estimated that $22 \%$ of them will not graduate from high school. This high dropout rate increases to $32 \%$ for students who spend half of their life in poverty (Hernandez, 2012). These statistics are in stark contrast to the dropout rate of $6 \%$ for students who were never in a poverty situation.

Concerning Texas, McGown (2016) analyzed the reading performance of Texas elementary school students as a function of their economic status. In her multiyear investigation, McGown analyzed three years (i.e., 2012-2013, 2013-2014, 2014-2015) of Texas data on the State of Texas Assessment of Academic Readiness (STAAR). Examined in her study were the three STAAR Reading Reporting Categories and the percentage of students who met the Level II Final Satisfactory Performance Standard. Economic status, in McGown's (2016) research investigation, consisted of three groups, based upon their eligibility for the federal free or reduced-price lunch 
program. Students who were eligible for a free lunch were defined as Extremely Poor, students who were eligible for a reduced-price lunch were regarded as Moderately Poor, and students who were not eligible for either program were defined as Not Poor. According to Burney and Beilke (2008), families who earn incomes above $185 \%$ of the Federal poverty line do not qualify for the Federal free or reduced lunch program. Students who are classified as Poor qualify for the Federal free lunch program and reduced-lunch program in this journal-ready dissertation. Families who earn an income of $130 \%$ or less than the Federal poverty line meets the requirements for the Federal freelunch program (Burney \& Beilke, 2008). Students who qualify for the Federal reduced-lunch program in this journal-ready dissertation. Families who earn incomes between $131 \%$ to $185 \%$ of the Federal poverty line meet the requirements for the Federal reduced-lunch program (Burney \& Beilke, 2008).

McGown (2016) documented the presence of strong relationships between student poverty and reading below grade level On all three STAAR Reading Reporting categories, students who were in the Not Poor group had the highest reading performance, followed by students in the Moderately Poor group, and then by students in the Extremely Poor group. This clear stair-step effect (Ramirez, \& Severn, 2006) was present in all three school years and for all three STAAR Reading Reporting categories. Effect sizes for these statistically significant differences ranged from small to moderate in nature.

Concerning the percentages of students who met the state-mandated performance standards, McGown (2016) established the presence of statistically significant differences among the three groups of students. In all three school years, higher percentages of students who were in the Not Poor group met the performance standard, followed by students who were in the Moderately Poor group, and then by students in the Extremely Poor group. The differences in the percentages of students who met the state-mandated performance standard between the Not Poor and Moderately Poor groups of students were 18.9\% (2012-2013), 19.4\% (2013-2014), and 19.9\% (2014-2015). The differences in the percentages who met the state-mandated performance standard were the greatest between students who were in the Not Poor group and students who were in the Extremely Poor group, with the differences being 28.8\% (2012-2013), 30.9\% (2013-2014), and 29.3\% (2014-2015).

In a similar multiyear analysis that was also conducted in Texas, Harris (2018) analyzed the reading performance of Texas Grade 4 students as a function of their economic status. What was unique to Harris' (2018) investigation was her use of Grade 4 students as her sample. She analyzed Texas statewide STAAR Reading data from the 2012-2013, 2013-2014, and 2014-2015 school years. Economic status in Harris's (2018) research investigation was defined in the same manner as McGown (2016). Harris (2018) established that as poverty levels increased, student reading performance decreased. In all three school years, a clear stair-step effect (Carpenter et al., 2006) was present for the three STAAR Reading Reporting Categories. On all three STAAR Reading Reporting categories, Grade 4 students who were in the Not Poor group had the highest average raw scores, followed by students in the Moderately Poor group, and then by students in the Extremely Poor group. This clear stair-step effect (Carpenter et al., 2006) was present in all three school years 
and for all three STAAR Reading Reporting categories. Effect sizes for these statistically significant differences were moderate in all three school years.

Concerning the performance standards, in all three school years, higher percentages of Grade 4 students who were in the Not Poor group met the performance standard, followed by students who were in the Moderately Poor group, and then by students in the Extremely Poor group. The differences in the percentages of students who met the state-mandated performance standard between the Not Poor and Moderately Poor groups of students were 19.3\% (2012-2013), 18.7\% (2013-2014), and 19.7\% (2014-2015). The differences in the percentages who met the statemandated performance standard were the greatest between students who were in the Not Poor group and students who were in the Very Poor group, with the differences being 29.4\% (2012-2013), $27.9 \%$ (2013-2014), and 31.9\% (2014-2015).

In a similar investigation, but based on Grade 6 students, Wright and Slate (2015) examined data from the 2010-2011 Texas Assessment of Knowledge and Skills Reading assessment, the standardized test predecessor to the STAAR exam. Concerning economic status, students who were eligible for either the free or reduced-price lunch program were in the Economically Disadvantaged group, and students who were not eligible for either the free or reduced-price lunch program were in the Not Economically Disadvantaged group. Wright and Slate (2015) documented the presence of a $4 \%$ to $6 \%$ lower performance in the reading of students in poverty in comparison to their peers who were not in poverty. Wright and Slate (2015) stated, "the academic achievement gap between students who were or were not economically disadvantaged has grown substantially over the past few generations" (p. 345).

Additionally, Reardon (2011) analyzed five decades of academic achievement data by student economic status. Reardon (2011) ascertained that over the last 50 years, the association between parental education and student achievement has remained stable, although the association between parental income and student achievement has dramatically increased. Reardon (2011) suggested the increase over time between the relationship between parental income and student achievement was due to an increase in parent involvement, as family income increased, in their children's cognitive development in recent years. Similar to parental education, economic status was a strong predictor of student academic achievement (Reardon, 2011).

In another recent investigation, directly related to the sample of students whose data will be analyzed in this investigation, Jones, Ostojic, Menard, Picard, and Miller (2017) sought to identify factors that most contributed to poor student reading outcomes. Of particular interest to this article was their examination of the relationship between reading performance, economic status, and special education status. Specifically analyzed were the 2011-2013 achievement tests results of 1,429 Grade 3 students from Southwestern Ontario. Jones et al. argued that the students who were at the highest risk (i.e., economically disadvantaged students, English Language Learners, or in special education) for poor reading outcomes did not make the same reading performance gains as their peers in higher-income schools. 
Families with incomes below the federal poverty threshold are considered poor. The cost of raising a child with simply the basic needs requires at least twice the federal poverty threshold, resulting in the actual percentage of children living in poverty in the US being closer to $43 \%$ (National Center for Children in Poverty, 2019). According to the U.S. Department of Agriculture (2017), the cost of raising a child from birth to age 18 is almost $\$ 240,000$, while the cost of raising a child with special needs can be up to $\$ 1,000,000$ (National Center for Children in Poverty, 2019). Researchers (e.g., Harris, 2018; Hernandez, 2012; McGown, 2016; Reardon, 2011; Wright \& Slate, 2015) have all demonstrated that childhood poverty is a substantial threat to the ability of children to learn, thereby negatively affecting the ability to read. Students in special education are more likely to be raised in poverty, tend to struggle with reading at greater rates, and respond less effectively to academic interventions (Jones et al., 2017). Consequently, the limited research available on the reading performance of students who are in special education and poverty was addressed to provide empirical insights and ensure a firm foundation to develop educational practices for student learning.

The purpose of this study was to examine the degree to which differences existed in reading by the economic status of Texas Grade 4 boys and girls in special education. In this study, student economic status consisted of two groups of students: Not Economically Disadvantaged and Economically Disadvantaged. Specifically examined was the effect of economic status on the ability of Grade 4 boys and girls in special education to understand a variety of written texts across reading genres, the ability to understand and analyze literary texts, and the ability to understand and analyze informational texts. A second purpose was to determine the degree to which economic status was related to student performance across the three phase-in performance standards for Grade 4 boys and girls in special education. A third purpose was to determine the extent to which trends were present across the reporting categories for four school years by the economic status of Grade 4 boys and girls in special education. A fourth purpose was to determine the extent to which trends were present across the three phase-in standards across four school years (i.e., 2014-2015, 20152016, 2016-2017, 2017-2018).

A substantial amount of literature exists on the relationships of reading with? gender, special education enrollment, and economic status separately?. However, research is limited on the interaction of all four variables. Though researchers (Harris, 2018; McGown, 2016) have recently examined reading performance and trends for the STAAR Reading Reporting Categories I, II, and III and the STAAR Reading Phase-in 1, 2, and 3 Satisfactory performance standards, no studies were located in which researchers examined reading by the economic status of students in special education. Accordingly, gaps in the existing literature may be filled as a result of this study. Additionally, school leaders and policymakers may gain insights for improving instruction for students with disabilities.

The following overarching research question was addressed in this study: What is the effect of economic status on the overall reading performance of Grade 4 students in special education? Within the overarching research question eight sub-questions were present: (a) What is the effect of 
economic status on the ability of Grade 4 students in special education to understand a variety of written texts across reading genres (i.e., STAAR Reading Reporting Category I)?; (b) What is the effect of economic status on the ability of Grade 4 students in special education to understand and analyze literary texts (i.e., STAAR Reading Reporting Category II)?; (c) What is the effect of economic status on the ability of Grade 4 students in special education to understand and analyze informational texts (i.e., STAAR Reading Reporting Category III)?; (d) What is the effect of economic status on the STAAR Reading Phase-in 1 standard of Grade 4 students in special education?; (e) What is the effect of economic status on the STAAR Reading Phase-in 2 standard of Grade 4 students in special education?; (f) What is the effect of economic status on the STAAR Reading Phase-in 3 standard of Grade 4 students in special education?; (g) What trend is present across the STAAR Reading Reporting Categories I, II, and III by the economic status of Grade 4 students across four school years of data?; and (h) What trend is present across the STAAR Reading Phase-in 1, 2, and 3 Satisfactory performance standards by the economic status of Grade 4 students across four school years of data? The first six research questions were addressed separately for boys and girls and were repeated for four school years. The last two research questions involved comparisons across all four school years (i.e., 2014-2015, 2015-2016, 2016-2017, 2017-2018).

\section{Methods}

\subsection{Research Design}

For this empirical investigation, a non-experimental, causal-comparative research design was used (Creswell \& Creswell, 2018; Johnson \& Christensen, 2017). In such a design, pre-existing or secondary data are used. As such, no variables can be manipulated or controlled. In this investigation, a state archival dataset was analyzed to determine the effect of economic status on the overall reading performance of Grade 4 students in special education. The independent variable involved in this research article was economic status (i.e., Not Economically Disadvantaged, Economically Disadvantaged). The dependent variables were the STAAR Reading Reporting Categories 1, 2, and 3 of boys and girls in special education and the Phase-In Satisfactory Performance Standards 1, 2, and 3 of boys and girls in special education.

\subsection{Participants And Instrumentation}

Data for this study were obtained from the Texas Education Agency Public Education Information Management System Texas state-mandated reading assessment for the 2014-2015, 2015-2016, 2016-2017, and the 2017-2018 school years. These data were analyzed to determine the degree to which students' economic status was related to their reading performance in each of the four school years. Also addressed was the extent to which trends were present in reading performance by the economic status of Grade 4 boys and girls in special education across four school years of data. Additional analyses were conducted to identify trends across the STAAR Reading Reporting Categories I, II, and III and across the STAAR Reading Phase-in 1, 2, and 3 Satisfactory performance standards by student economic status. 
All statistical analyses were conducted separately for boys and girls due to the gender disproportionality that exists in special education and the potential that this disparity could skew the overall results. In Texas, the under-identification of girls, and/or the over-identification of boys, in special education is apparent in enrollment data. That is, girls, account for $33 \%$ of the special education population, yet they constitute $49 \%$ of the overall public school enrollment (Texas Education Agency, 2018b). Gender disproportionality is also present at the national level with public school students in special education representing $17 \%$ percent of boys and $9 \%$ of girls (National Center for Education Statistics, 2019a).

The federal poverty threshold varies by calendar year and is updated each January by adjusting the threshold from the prior year to inflation identified in the Consumer Price Index. For 2019, the poverty threshold for the 48 contiguous states and the District of Columbia was: (a) $\$ 12,490$ for a single person household; (b) $\$ 16,910$ for a two-person household; (c) $\$ 21,330$ for a three-person household; (d) $\$ 25,750$ for a four-person household; (e) $\$ 30,170$ for a five-person household; (f) $\$ 34,590$ for a six-person household; (g) $\$ 39,010$ for a seven-person household; and (h) \$43,430 for an eight-person household (U.S. Department of Health and Human Services, 2019). In this study, the economic status will refer to two groups of students. For the purpose of this article, students who did not qualify for free or reduced lunch (i.e., household income of more than $185 \%$ of the Federal poverty threshold) were in the Not Economically Disadvantaged group. Students who qualified for the reduced lunch program (i.e., household income of between $131 \%$ to $185 \%$ of the Federal poverty threshold) or the free lunch program (i.e., family income of $130 \%$ or less of the Federal poverty threshold) were considered to be Economically Disadvantaged (Burney \& Beilke, 2008).

Reading performance was based on the STAAR Reading Reporting Categories. The Texas Education Agency (2011) has defined the STAAR Reading Reporting Category I as an indicator measuring a student's ability, "to understand and analyze a variety of written texts across reading genres" (p. 2). In contrast, the STAAR Reading Reporting Category II is defined as an indicator measuring a student's ability, "to understand and analyze literary texts" (p. 3) and the STAAR Reading Reporting Category III was defined as an indicator measuring a student's ability, "to understand and analyze informational texts" (p. 5).

In addition to data analyses of the three STAAR Reading Reporting Categories, student reading performance on the STAAR Phase-in standards 1, 2, and 3 were also examined. Meeting the STAAR Satisfactory criteria requires that a student meet a minimum scaled score based on the Phase-in performance standard in place during the school year of the assessment. The minimum scaled scores were designed to increase in three phases over 5-year period. The English STAAR Grade 4 Reading assessment for the 2014-2015 school year (i.e., Phase-in 1) required a scaled score of 1422 for a Satisfactory performance designation, for 2015-2016 through 2017-2018 (i.e., Phasein 2) a minimum scaled score of 1460 was required, and for the 2018-2019 (i.e., Phase-in 3) school year the minimum required scale score was 1511. Examining the STAAR Satisfactory criteria across each of the Phase-in standards enabled a comparison of student reading achievement data 
across the four school years of data even though the satisfactory performance scaled scores changed.

\section{Results and Discussion}

Prior to conducting multivariate analysis of variance (MANOVA) procedures to address the research questions previously delineated, its underlying assumptions were checked. Specifically examined were data normality, Box's Test of Equality of Covariance, and the Levene's Test of Equality of Error Variances. Although these assumptions were not met, the robustness of a MANOVA procedure made it appropriate to use on the data in this study (Field, 2009). Results will be presented in chronological order beginning with the 2014-2015 school year and concluding with the 2017-2018 school year.

\subsection{Overall Results for Boys Across All Four School Years}

For the 2014-2015 school year, the MANOVA yielded a statistically significant difference in overall reading performance by the economic status of Grade 4 boys in special education, Wilks' $\Lambda$ $=.91, p<.001$, partial $\eta^{2}=.09$, moderate effect size (Cohen, 1988). With respect to the 2015-2016 school year, a statistically significant difference was present in overall reading performance, Wilks' $\Lambda=.85, p<.001$, partial $\eta^{2}=.15$, large effect size (Cohen, 1988). Concerning the 2016-2017 school year, a statistically significant difference was yielded, Wilks' $\Lambda=.90, p<.001$, partial $\eta^{2}=$ .10 , a moderate effect size (Cohen, 1988). Regarding the 2017-2018 school year, a statistically significant difference was again present in overall reading, Wilks' $\Lambda=.99, p=.006$, partial $\eta^{2}=$ .01 , small effect size (Cohen, 1988). One effect size was large, two effect sizes were moderate, and one effect size was small.

\subsection{Results for Reading Reporting Category I for Boys Across All Four School Years}

For each of the four school years, a univariate follow-up analysis of variance (ANOVA) procedures was calculated to determine whether statistically significant differences were present for the STAAR Reading Reporting Category I scores by economic status. Concerning the 2014-2015 school year, a statistically significant difference was revealed, $F(1,845)=85.08, p<.001$, partial $\eta^{2}$ $=.09$, moderate effect size (Cohen, 1988). For the 2015-2016 school year, the ANOVA yielded a statistically significant difference, $F(1,947)=129.75, p<.001$, partial $\eta^{2}=.12$, moderate effect size (Cohen, 1988), on the STAAR Reading Reporting Category I by student economic status. Regarding the 2016-2017 school year, a statistically significant difference was again revealed, $F(1$, $1157)=107.76, p<.001$, partial $\eta^{2}=.08$, moderate effect size (Cohen, 1988). With respect to the 2017-2018 school year, a statistically significant difference was yielded, $F(1,890)=4.70, p=.03$, partial $\eta^{2}=.01$, a small effect size (Cohen, 1988). In all four school years, Grade 4 boys in special education who were Economically Disadvantaged answered statistically significantly fewer items correctly on the STAAR Reading Reporting Category I than boys who were Not Economically Disadvantaged. Three of the effect sizes were moderate and one effect size was in the below small category. 
Concerning the 2014-2015, 2015-2016, and 2016-2017 school years, Grade 4 boys in special education who were Economically Disadvantaged answered, on average, over one and one-half items fewer correctly than was answered correctly by boys who were Not Economically Disadvantaged. Economically Disadvantaged boys answered, on average, about one-half a question fewer correctly than boys who were Not Economically Disadvantaged in the 2017-2018 school year. Descriptive statistics are contained in Table 1.

Table 1. Descriptive Statistics for the STAAR Reading Reporting Category I by the Economic Status of Grade 4 Boys in Special Education for the 2014-2015 School Year through the 2017-2018 School Year

\begin{tabular}{lccc}
\hline School Year and Economic Status & $\boldsymbol{n}$ & $\boldsymbol{M}$ & $\boldsymbol{S D}$ \\
\hline 2014-2015 & & & \\
$\quad$ Not Economically Disadvantaged & 346 & 4.48 & 3.82 \\
$\quad$ Economically Disadvantaged & 501 & 2.55 & 2.25 \\
2015-2016 & & & \\
$\quad$ Not Economically Disadvantaged & 349 & 5.84 & 3.66 \\
$\quad$ Economically Disadvantaged & 600 & 3.56 & 2.49 \\
2016-2017 & 310 & 4.63 & 3.01 \\
$\quad$ Not Economically Disadvantaged & 849 & 3.00 & 2.07 \\
$\quad$ Economically Disadvantaged & 153 & 3.39 & 3.06 \\
2017-2018 & 739 & 2.98 & 1.92 \\
$\quad$ Not Economically Disadvantaged & & & \\
$\quad$ Economically Disadvantaged & &
\end{tabular}

\subsection{Results for Reading Reporting Category II for Boys Across All Four School Years}

Concerning the 2014-2015 school year, a statistically significant difference was revealed, $F(1$, $845)=76.73, p<.001$, partial $\eta^{2}=.08$, moderate effect size (Cohen, 1988). For the 2015-2016 school year, the ANOVA yielded a statistically significant difference, $F(1,947)=106.84, p<.001$, partial $\eta^{2}=.10$, moderate effect size (Cohen, 1988). Regarding the 2016-2017 school year, a statistically significant difference was again revealed, $F(1,1157)=79.24, p<.001$, partial $\eta^{2}=.08$, moderate effect size (Cohen, 1988). With respect to the 2017-2018 school year, a statistically significant difference was yielded, $F(1,890)=9.80, p=.002$, partial $\eta^{2}=.01$, a small effect size (Cohen, 1988). In all four school years, Grade 4 boys in special education who were Economically Disadvantaged answered a statistically significantly fewer number of items on the STAAR Reading Reporting Category II than students who were Not Economically Disadvantaged. Three effect sizes were moderate and one effect size was small.

Regarding the STAAR Reading Reporting Category II, during the 2014-2015 and 2015-2016 school years, Grade 4 boys in special education who were Economically Disadvantaged answered, on average, over three and one-quarter items fewer correctly than was answered correctly by boys who were Not Economically Disadvantaged. In 2016-2017, Grade 4 boys in special education who were Economically Disadvantaged answered, on average, two and one-quarter items fewer correctly 
than were answered correctly by boys who were Not Economically Disadvantaged. Economically Disadvantaged boys answered, on average, about one fewer question correctly than boys who were Not Economically Disadvantaged in 2017-2018. Descriptive statistics for the STAAR Reading Reporting Category II are contained in Table 2.

Table 2. Descriptive Statistics for the STAAR Reading Reporting Category II by the Economic Status of Grade 4 Boys in Special Education for the 2014-2015 School Year through the 2017-2018 School Year

\begin{tabular}{lccc}
\hline School Year and Economic Status & $\boldsymbol{n}$ & $\boldsymbol{M}$ & $\boldsymbol{S} \boldsymbol{D}$ \\
\hline 2014-2015 & 346 & 8.24 & 6.82 \\
$\quad$ Not Economically Disadvantaged & 501 & 4.96 & 4.06 \\
$\quad$ Economically Disadvantaged & 349 & 9.50 & 5.83 \\
2015-2016 & 600 & 6.28 & 3.74 \\
$\quad$ Not Economically Disadvantaged & & & \\
$\quad$ Economically Disadvantaged & 310 & 7.94 & 5.24 \\
2016-2017 & 849 & 5.65 & 3.24 \\
$\quad$ Not Economically Disadvantaged & & & \\
Economically Disadvantaged & 153 & 6.16 & 5.39 \\
2017-2018 & 739 & 5.12 & 3.28 \\
$\quad$ Not Economically Disadvantaged & & & \\
$\quad$ Economically Disadvantaged &
\end{tabular}

\subsection{Results for Reading Reporting Category III for Boys Across All Four School Years}

Concerning the 2014-2015 school year, a statistically significant difference was revealed, $F(1$, $845)=74.99, p<.001$, partial $\eta^{2}=.08$, moderate effect size (Cohen, 1988), on the STAAR Reading Reporting Category III by student economic status. Regarding the 2015-2016 school year, the ANOVA yielded a statistically significant difference, $F(1,947)=155.06, p<.001$, partial $\eta^{2}=.14$, large effect size (Cohen, 1988). For the 2016-2017 school year, a statistically significant difference was again revealed, $F(1,1157)=122.43, p<.001$, partial $\eta^{2}=.10$, moderate effect size (Cohen, 1988). With respect to the 2017-2018 school year, a statistically significant difference was yielded, $F(1,890)=11.05, p=.001$, partial $\eta^{2}=.01$, a small effect size (Cohen, 1988). In all four school years, Grade 4 boys in special education who were Economically Disadvantaged answered statistically significantly fewer items on the STAAR Reading Reporting Category III than boys who were Not Economically Disadvantaged. One effect size was large, two were moderate, and one effect size was small.

Concerning the 2014-2015, 2015-2016, and 2016-2017 school years, Grade 4 boys in special education who were Economically Disadvantaged answered, on average, over two and one-half items fewer correctly than was answered correctly by boys who were Not Economically Disadvantaged. Economically Disadvantaged boys answered, on average, about one fewer 
questions correctly than boys who were Not Economically Disadvantaged in 2017-2018. Descriptive statistics for the STAAR Reading Reporting Category III are presented in Table 3.

Table 3. Descriptive Statistics for the STAAR Reading Reporting Category III by the Economic Status of Grade 4 Boys in Special Education for the 2014-2015 School Year through the 2017-2018 School Year

\begin{tabular}{llll}
\hline School Year and Economic Status & $\boldsymbol{n}$ & $\boldsymbol{M}$ & $\boldsymbol{S D}$ \\
\hline 2014-2015 & & & \\
$\quad$ Not Economically Disadvantaged & 346 & 6.94 & 5.96 \\
$\quad$ Economically Disadvantaged & 501 & 4.08 & 3.62 \\
2015-2016 & & & \\
$\quad$ Not Economically Disadvantaged & 349 & 8.59 & 5.31 \\
$\quad$ Economically Disadvantaged & 600 & 5.19 & 3.11 \\
2016-2017 & & & \\
$\quad$ Not Economically Disadvantaged & 310 & 6.18 & 4.45 \\
$\quad$ Economically Disadvantaged & 849 & 3.86 & 2.53 \\
2017-2018 & & & \\
$\quad$ Not Economically Disadvantaged & 153 & 5.50 & 4.88 \\
$\quad$ Economically Disadvantaged & 739 & 4.51 & 2.92 \\
\hline
\end{tabular}

\subsection{Overall Results for Girls Across All Four School Years}

For the 2014-2015 school year, the MANOVA yielded a statistically significant difference in overall reading performance by the economic status of Grade 4 girls in special education, Wilks' $\Lambda$ $=.91, p<.001$, partial $\eta^{2}=.09$, moderate effect size (Cohen, 1988). With respect to the 2015-2016 school year, a statistically significant difference was present, Wilks' $\Lambda=.85, p<.001$, partial $\eta^{2}=$ .15 , large effect size (Cohen, 1988). Concerning the 2016-2017 school year, a statistically significant difference was yielded, Wilks' $\Lambda=.90, p<.001$, partial $\eta^{2}=.10$, a moderate effect size (Cohen, 1988). Regarding the 2017-2018 school year, a statistically significant difference was not present in overall reading, Wilks' $\Lambda=.96, p=.065$. One effect size was large and two effect sizes were moderate.

\subsection{Results for Reading Reporting Category I for Girls Across All Four School Years}

Concerning the 2014-2015 school year, a statistically significant difference was not revealed, $F(1,241)=0.92, p=.34$, for girls on the STAAR Reading Reporting Category I. For the 20152016 school year, the ANOVA yielded a statistically significant difference, $F(1,142)=10.63, p=$ .001 , partial $\eta^{2}=.07$, moderate effect size (Cohen, 1988). Regarding the 2016-2017, a statistically significant difference was not revealed, $F(1,221)=0.38, p=.54$, for girls. In 2017-2018, a statistically significant difference was not present, $F(1,157)=1.89, p=.17$. Of the four school years of data analyzed, in only one school year, 2015-2016, did economic status affect the reading performance of Grade 4 girls in special education. The effect size for this school year was moderate. 
Concerning the 2015-2016 school year, Grade 4 girls in special education who were Economically Disadvantaged answered, on average, over one and three-quarter items fewer correctly on the STAAR Reading Reporting Category 1 than was answered correctly by girls who were Not Economically Disadvantaged. In the other three school years, girls in special education, regardless of their economic status, answered a similar number of items correctly on this reading reporting category. Descriptive statistics are presented in Table 4.

Table 4. Descriptive Statistics for the STAAR Reading Reporting Category I by the Economic Status of Grade 4 Girls in Special Education for the 2014-2015 School Year through the 2017-2018 School Year

\begin{tabular}{lccc}
\hline School Year and Economic Status & $\boldsymbol{n}$ & $\boldsymbol{M}$ & $\boldsymbol{S D}$ \\
\hline 2014-2015 & & & \\
$\quad$ Not Economically Disadvantaged & 80 & 1.46 & 3.02 \\
$\quad$ Economically Disadvantaged & 163 & 1.81 & 2.46 \\
2015-2016 & & & \\
$\quad$ Not Economically Disadvantaged & 50 & 3.92 & 4.36 \\
$\quad$ Economically Disadvantaged & 94 & 2.13 & 2.25 \\
2016-2017 & 60 & 2.93 & 3.23 \\
$\quad$ Not Economically Disadvantaged & 163 & 2.71 & 2.08 \\
$\quad$ Economically Disadvantaged & & & \\
2017-2018 & 43 & 1.88 & 2.59 \\
$\quad$ Not Economically Disadvantaged & 116 & 2.45 & 2.18 \\
$\quad$ Economically Disadvantaged & & &
\end{tabular}

3.7 Results for Reading Reporting Category II for Girls Across All Four School Years

Concerning the 2014-2015 school year, a statistically significant difference was not revealed $F(1,241)=1.03, p=.31$, for girls. For the 2015-2016 school year, the ANOVA yielded a statistically significant difference, $F(1,142)=9.93, p=.006$, partial $\eta^{2}=.05$, small effect size (Cohen, 1988). Regarding the 2016-2017 school year, a statistically significant difference was not revealed, $F(1,221)=0.59, p=.44$. In 2017-2018 a statistically significant difference was also not present, $F(1,157)=0.10, p=.92$. Only in 2015-2016 was a statistically significant effect present. The effect size for this difference was small.

Regarding the STAAR Reading Reporting Category II, during the 2015-2016 school year, Grade 4 girls in special education who were Economically Disadvantaged answered, on average, over two and one-half items fewer correctly than was answered correctly by girls who were Not Economically Disadvantaged. Economically Disadvantaged girls and girls who were Not Economically Disadvantaged answered a similar number of questions correctly on the STAAR Reading Reporting Category II in the other three school years. Delineated in Table 5 are the descriptive statistics for these school years. 
Table 5. Descriptive Statistics for the STAAR Reading Reporting Category II by the Economic Status of Grade 4 Girls in Special Education for the 2014-2015 School Year through the 2017-2018 School Year

\begin{tabular}{lccc}
\hline School Year and Economic Status & $\boldsymbol{n}$ & $\boldsymbol{M}$ & $\boldsymbol{S D}$ \\
\hline 2014-2015 & & & \\
$\quad$ Not Economically Disadvantaged & 80 & 3.11 & 6.19 \\
$\quad$ Economically Disadvantaged & 163 & 3.84 & 4.73 \\
2015-2016 & & & \\
$\quad$ Not Economically Disadvantaged & 50 & 6.44 & 7.16 \\
$\quad$ Economically Disadvantaged & 94 & 3.91 & 3.62 \\
2016-2017 & & & \\
$\quad$ Not Economically Disadvantaged & 60 & 4.88 & 5.49 \\
$\quad$ Economically Disadvantaged & 163 & 5.37 & 3.61 \\
2017-2018 & 43 & 3.88 & 5.27 \\
$\quad$ Not Economically Disadvantaged & 116 & 3.96 & 3.69 \\
$\quad$ Economically Disadvantaged & & & \\
\hline
\end{tabular}

\subsection{Results for Reading Reporting Category III for Girls Across All Four School Years}

Concerning the 2014-2015 school year, a statistically significant difference was not present, $F(1,241)=0.20, p=.66$, for girls. For the 2015-2016 school year, the ANOVA yielded a statistically significant difference, $F(1,142)=5.82, p=.017$, partial $\eta^{2}=.04$, small effect size (Cohen, 1988). Regarding the 2016-2017 school year, a statistically significant difference was not revealed, $F(1,221)=0.68, p=.41$. In 2017-2018, a statistically significant difference was also not yielded, $F(1,157)=0.16, p=.69$. Only for the 2015-2016 school year was a statistically significant difference present, with a small effect size.

Concerning the 2015-2016 school year, Grade 4 girls in special education who were Economically Disadvantaged answered, on average, nearly two items fewer correctly than was answered correctly by girls who were Not Economically Disadvantaged. In the other three school years, Grade 4 girls who were Economically Disadvantaged and who were Not Economically Disadvantaged answered correctly a similar number of items in this reading category. Revealed in Table 6 are the descriptive statistics for these school years.

\subsection{Results for the STAAR Reading Phase-in 1 Standard for Boys Across All Four School Years}

Student performance on the STAAR Reading Phase-in 1 standard was examined next through the use of Pearson chi-square procedures. Concerning the STAAR Reading Phase-in 1 standard by the economic status of Grade 4 boys, the result for the 2014-2015 school year was statistically significant, $\chi^{2}(1)=167.92, p<.001$. The effect size for this finding, Cramer's V, was large, .50 (Cohen, 1988). The Economically Disadvantaged group had 4.62 times fewer boys who met this standard than the Not Economically Disadvantaged group of boys. Table 7 contains the frequencies and percentages for the 2014-2015 school year. 
Table 6. Descriptive Statistics for the STAAR Reading Reporting Category III by the Economic Status of Grade 4 Girls in Special Education for the 2014-2015 School Year through the 2017-2018 School Year

\begin{tabular}{lccc}
\hline School Year and Economic Status & $\boldsymbol{n}$ & $\boldsymbol{M}$ & $\boldsymbol{S D}$ \\
\hline 2014-2015 & & & \\
$\quad$ Not Economically Disadvantaged & 80 & 2.48 & 5.03 \\
$\quad$ Economically Disadvantaged & 163 & 2.72 & 3.58 \\
2015-2016 & 50 & 5.58 & 6.23 \\
$\quad$ Not Economically Disadvantaged & 94 & 3.62 & 3.54 \\
$\quad$ Economically Disadvantaged & & & \\
2016-2017 & 60 & 3.95 & 4.85 \\
$\quad$ Not Economically Disadvantaged & 163 & 3.53 & 2.57 \\
$\quad$ Economically Disadvantaged & & & \\
2017-2018 & 43 & 3.42 & 4.85 \\
$\quad$ Not Economically Disadvantaged & 116 & 3.69 & 3.29 \\
$\quad$ Economically Disadvantaged & & &
\end{tabular}

Table 7. Frequencies and Percentages for the STAAR Reading Phase-in 1 Standard by the Economic Status of Grade 4 Boys in Special Education for the 2014-2015 School Year through the 2017-2018 School Year

\begin{tabular}{lcccc}
\hline & \multicolumn{2}{c}{ Met Standard } & \multicolumn{2}{c}{ Did Not Meet Standard } \\
\cline { 2 - 5 } School Year and Economic Status & $\boldsymbol{n}$ & $\mathbf{\%}$ & $\boldsymbol{n}$ & $\boldsymbol{\%}$ \\
\hline 2014-2015 & & & & \\
$\quad$ Not Economically Disadvantaged & 179 & 51.70 & 167 & 48.30 \\
$\quad$ Economically Disadvantaged & 56 & 11.20 & 445 & 88.80 \\
2015-2016 & & & & \\
$\quad$ Not Economically Disadvantaged & 201 & 57.60 & 148 & 42.40 \\
$\quad$ Economically Disadvantaged & 97 & 16.20 & 503 & 83.80 \\
2016-2017 & & & & \\
$\quad$ Not Economically Disadvantaged & 176 & 56.80 & 134 & 43.20 \\
$\quad$ Economically Disadvantaged & 117 & 13.80 & 732 & 86.20 \\
2017-2018 & & & & \\
$\quad$ Not Economically Disadvantaged & 70 & 45.80 & 83 & 54.20 \\
$\quad$ Economically Disadvantaged & 112 & 15.20 & 627 & 84.80 \\
\hline
\end{tabular}

With regard to the 2015-2016 school year, the result was statistically significant, $\chi^{2}(1)=$ $175.79, p<.001$, moderate effect size Cramer's V of .43 (Cohen, 1988). As presented in Table 2.7, the Economically Disadvantaged group had 3.67 times fewer boys who met this standard than the Not Economically Disadvantaged group of boys. Concerning the 2016-2017 school year, a statistically significant difference was revealed, $\chi^{2}(1)=222.21, p<.001$, moderate effect size, Cramer's V of .44 (Cohen, 1988). As delineated in Table 7, the Economically Disadvantaged group had 4.12 times fewer boys who met this standard than the Not Economically Disadvantaged group of boys. With regard to the 2017-2018 school year, the result was statistically significant, $\chi^{2}(1)=$ 73.06, $p<.001$, small effect size, Cramer's V of .29 (Cohen, 1988). The Economically 
Disadvantaged group, as revealed in Table 7, had 3.01 times fewer boys who met this standard than the Not Economically Disadvantaged group of boys.

\subsection{Results for the STAAR Reading Phase-in 2 Standard for Boys Across All Four School Years}

Concerning the STAAR Reading Phase-in 2 standard by the economic status of Grade 4 boys, the result for the 2014-2015 school year was statistically significant, $\chi^{2}(1)=173.54, p<.001$, large effect size, Cramer's V of .50 (Cohen, 1988). The Economically Disadvantaged group had 54 times fewer boys who met this standard than the Not Economically Disadvantaged group of boys. Table 8 contains the frequencies and percentages for the 2014-2015 school year.

Table 8. Frequencies and Percentages for the STAAR Reading Phase-in 2 Standard by the Economic Status of Grade 4 Boys in Special Education for the 2014-2015 School Year through the 2017-2018 School Year

\begin{tabular}{lcccc}
\hline & \multicolumn{2}{c}{ Met Standard } & \multicolumn{2}{c}{ Did Not Meet Standard } \\
\cline { 2 - 5 } School Year and Economic Status & $\boldsymbol{n}$ & $\mathbf{\%}$ & $\boldsymbol{n}$ & $\mathbf{\%}$ \\
\hline 2014-2015 & 107 & 37.80 & 176 & 62.20 \\
$\quad$ Not Economically Disadvantaged & 3 & 0.70 & 410 & 99.30 \\
$\quad$ Economically Disadvantaged & & & & \\
2015-2016 & 126 & 36.10 & 223 & 63.90 \\
$\quad$ Not Economically Disadvantaged & 18 & 3.00 & 582 & 97.00 \\
$\quad$ Economically Disadvantaged & & & & \\
2016-2017 & 116 & 37.40 & 194 & 62.60 \\
$\quad$ Not Economically Disadvantaged & 28 & 3.30 & 821 & 96.70 \\
$\quad$ Economically Disadvantaged & & & & \\
2017-2018 & 39 & 25.50 & 114 & 74.50 \\
$\quad$ Not Economically Disadvantaged & 34 & 4.60 & 705 & 95.40 \\
$\quad$ Economically Disadvantaged & & &
\end{tabular}

With respect to the 2015-2016 school year, a statistically significant difference was yielded, $\chi^{2}(1)=187.86, p<.001$, moderate effect size, Cramer's V of .44 (Cohen, 1988). As presented in Table 2.8, the Economically Disadvantaged group had 12.03 times fewer boys who met this standard than the Not Economically Disadvantaged group of boys. Concerning the 2016-2017 school year, the result was statistically significant, $\chi^{2}(1)=242.98, p<.001$, moderate effect size, Cramer's V of .46 (Cohen, 1988). As delineated in Table 8, the Economically Disadvantaged group had 11.33 times fewer boys who met this standard than the Not Economically Disadvantaged group of boys. Regarding the 2017-2018 school year, the result was statistically significant, $\chi^{2}(1)=73.61$, $p<.001$, small effect size, Cramer's V of .29 (Cohen, 1988). The Economically Disadvantaged group, as revealed in Table 8, had 5.54 times fewer boys who met this standard than the Not Economically Disadvantaged group of boys.

\subsection{Results for the STAAR Reading Phase-in 3 Standard for Boys Across All Four School Years}

Concerning the STAAR Reading Phase-in 3 standard by the economic status of Grade 4 boys, the result for the 2014-2015 school year was statistically significant, $\chi^{2}(1)=81.83, p<.001$, 
moderate effect size, Cramer's V of .31 (Cohen, 1988). The Economically Disadvantaged group had 22 times fewer boys who met this standard than the Not Economically Disadvantaged group of boys. Table 9 contains the frequencies and percentages for the 2014-2015 school year.

Table 9. Frequencies and Percentages for the STAAR Reading Phase-in 3 Standard by the Economic Status of Grade 4 Boys in Special Education for the 2014-2015 School Year through the 2017-2018 School Year

\begin{tabular}{lcccc}
\hline & \multicolumn{2}{c}{ Met Standard } & \multicolumn{2}{c}{ Did Not Meet Standard } \\
\cline { 2 - 5 } School Year and Economic Status & $\boldsymbol{n}$ & $\boldsymbol{\%}$ & $\boldsymbol{n}$ & $\boldsymbol{\%}$ \\
\hline 2014-2015 & 61 & 17.60 & 285 & 82.40 \\
$\quad$ Not Economically Disadvantaged & 4 & 0.80 & 497 & 99.20 \\
$\quad$ Economically Disadvantaged & & & & \\
2015-2016 & 67 & 80.80 & 282 & 19.20 \\
$\quad$ Not Economically Disadvantaged & 3 & 0.50 & 597 & 99.50 \\
$\quad$ Economically Disadvantaged & & & & \\
2016-2017 & 61 & 19.70 & 249 & 80.30 \\
$\quad$ Not Economically Disadvantaged & 15 & 1.80 & 834 & 98.20 \\
$\quad$ Economically Disadvantaged & & & & \\
2017-2018 & 20 & 13.10 & 133 & 86.90 \\
$\quad$ Not Economically Disadvantaged & 9 & 1.20 & 730 & 98.80 \\
$\quad$ Economically Disadvantaged & & &
\end{tabular}

Regarding the 2015-2016 school year, the result was statistically significant, $\chi^{2}(1)=112.91, p$ $<.001$, moderate effect size, Cramer's V of .34 (Cohen, 1988). As delineated in Table 2.7, the Economically Disadvantaged group had 161.60 times fewer boys who met this standard than the Not Economically Disadvantaged group of boys. Concerning the 2016-2017 school year, a statistically significant difference was yielded, $\chi^{2}(1)=118.89, p<.001$, moderate effect size, Cramer's V of .32 (Cohen, 1988). As revealed in Table 9, the Economically Disadvantaged group had 10.94 times fewer boys who met this standard than the Not Economically Disadvantaged group of boys. With regard to the 2017-2018 school year, the result was statistically significant, $\chi^{2}(1)=$ 56.63, $p<.001$, small effect size, Cramer's V of .25 (Cohen, 1988). The Economically Disadvantaged group, as revealed in Table 9, had 10.92 times fewer boys who met this standard than the Not Economically Disadvantaged group of boys.

\subsection{Results for the STAAR Reading Phase-in 1 Standard for Girls Across All Four School Year}

Concerning the STAAR Reading Phase-in 1 standard by the economic status of Grade 4 girls, the result for the 2014-2015 school year was statistically significant, $\chi^{2}(1)=2.24, p<.001$, small effect size, Cramer's V of .10 (Cohen, 1988). The Economically Disadvantaged group had 1.61 times fewer girls who met this standard than the Not Economically Disadvantaged group of girls. Table 10 contains the frequencies and percentages for the 2014-2015 school year. 
Table 10. Frequencies and Percentages for the STAAR Reading Phase-in 1 Standard by the Economic Status of Grade 4 Girls in Special Education for the 2014-2015 School Year through the 2017-2018 School Year

\begin{tabular}{lcccc}
\hline & \multicolumn{2}{c}{ Met Standard } & \multicolumn{2}{c}{ Did Not Meet Standard } \\
\cline { 2 - 5 } School Year and Economic Status & $\boldsymbol{n}$ & $\boldsymbol{\%}$ & $\boldsymbol{n}$ & $\boldsymbol{\%}$ \\
\hline 2014-2015 & 15 & 18.80 & 65 & 81.30 \\
$\quad$ Not Economically Disadvantaged & 19 & 11.70 & 144 & 88.30 \\
$\quad$ Economically Disadvantaged & & & & \\
2015-2016 & 22 & 44.00 & 28 & 56.00 \\
$\quad$ Not Economically Disadvantaged & 4 & 4.30 & 90 & 95.70 \\
Economically Disadvantaged & & & & \\
2016-2017 & 18 & 30.00 & 42 & 70.00 \\
$\quad$ Not Economically Disadvantaged & 19 & 11.70 & 144 & 88.30 \\
Economically Disadvantaged & & & & \\
2017-2018 & 12 & 27.90 & 31 & 72.10 \\
$\quad$ Not Economically Disadvantaged & 17 & 14.70 & 99 & 85.30 \\
$\quad$ Economically Disadvantaged & & & & \\
\hline
\end{tabular}

With regard to the 2015-2016 school year, a statistically significant difference was yielded, $\chi^{2}(1)=34.85, p<.001$, moderate/near large effect size, Cramer's V of .49 (Cohen, 1988). As presented in Table 10, the Economically Disadvantaged group had 10.23 times fewer girls who met this standard than the Not Economically Disadvantaged group of girls. Concerning the 2016-2017 school year, a statistically significant difference was revealed, $\chi^{2}(1)=10.66, p=.001$, small effect size, Cramer's V of .22 (Cohen, 1988). As delineated in Table 2.10, the Economically Disadvantaged group had 2.56 times fewer girls who met this standard than the Not Economically Disadvantaged group of girls. With respect to the 2017-2018 school year, the result was statistically significant, $\chi^{2}(1)=3.69, p=.055$, small effect size, Cramer's V of .15 (Cohen, 1988). The Economically Disadvantaged group, as revealed in Table 10, had 1.90 times fewer girls who met this standard than the Not Economically Disadvantaged group of girls.

\subsection{Results for the STAAR Reading Phase-in 2 Standard for Girls Across All Four School Years}

Concerning the STAAR Reading Phase-in 2 standard by the economic status of Grade 4 girls, the result for the 2014-2015 school year was statistically significant, $\chi^{2}(1)=10.25, p=.001$, small effect size, Cramer's V of, .27 (Cohen, 1988). The Economically Disadvantaged group had 6.30 times fewer girls who met this standard than the Not Economically Disadvantaged group of girls. Table 11 contains the frequencies and percentages for the 2014-2015 school year.

Regarding the 2015-2016 school year, the result was statistically significant, $\chi^{2}(1)=24.35, p<$ .001. The effect size yielded for this finding, Cramer's V, was moderate, .41 (Cohen, 1988). As presented in Table 11, the Economically Disadvantaged group had 14.28 times fewer girls who met this standard than the Not Economically Disadvantaged group of girls. Concerning the 2016-2017 school year, a statistically significant difference was yielded, $\chi^{2}(1)=10.66, p=.001$, small effect 
size, Cramer's V of .22 (Cohen, 1988). As delineated in Table 11, the Economically Disadvantaged group had 7.52 times fewer girls who met this standard than the Not Economically Disadvantaged group of girls. For the 2017-2018 school year, the result was statistically significant, $\chi^{2}(1)=4.53, p$ $=.033$, small effect size, Cramer's V of .17 (Cohen, 1988). The Economically Disadvantaged group, as revealed in Table 11, had 3.26 times more girls who met this standard than the Not Economically Disadvantaged group of girls.

Table 11. Frequencies and Percentages for the STAAR Reading Phase-in 2 Standard by the Economic Status of Grade 4 Girls in Special Education for the 2014-2015 School Year through the 2017-2018 School Year

\begin{tabular}{lcccc}
\hline & \multicolumn{2}{c}{ Met Standard } & \multicolumn{2}{c}{ Did Not Meet Standard } \\
\cline { 2 - 5 } School Year and Economic Status & $\boldsymbol{n}$ & $\mathbf{\%}$ & $\boldsymbol{n}$ & $\mathbf{\%}$ \\
\hline 2014-2015 & 7 & 18.90 & 30 & 81.10 \\
$\quad$ Not Economically Disadvantaged & 3 & 3.00 & 98 & 97.00 \\
$\quad$ Economically Disadvantaged & & & & \\
2015-2016 & 15 & 30.00 & 35 & 70.00 \\
$\quad$ Not Economically Disadvantaged & 2 & 2.10 & 92 & 97.90 \\
$\quad$ Economically Disadvantaged & & & & \\
2016-2017 & 14 & 23.30 & 46 & 76.70 \\
$\quad$ Not Economically Disadvantaged & 5 & 3.10 & 158 & 96.90 \\
$\quad$ Economically Disadvantaged & & & & \\
2017-2018 & 6 & 14.00 & 37 & 86.00 \\
$\quad$ Not Economically Disadvantaged & 5 & 4.30 & 111 & 95.70 \\
$\quad$ Economically Disadvantaged & & &
\end{tabular}

\subsection{Results for the STAAR Reading Phase-in 3 Standard for Girls Across All Four School Years}

Concerning the STAAR Reading Phase-in 3 standard by the economic status of Grade 4 girls, the result for the 2014-2015 school year was statistically significant, $\chi^{2}(1)=8.52, p=.004$, small effect size, Cramer's V of .19 (Cohen, 1988). The Economically Disadvantaged group had 7.33 times fewer girls who met this standard than the Not Economically Disadvantaged group of girls. Table 12 contains the frequencies and percentages for the 2014-2015 school year.

With regard to the 2015-2016 school year, a statistically significant difference was yielded, $\chi^{2}(1)=18.05, p<.001$, moderate effect size, Cramer's V of, .35 (Cohen, 1988). As presented in Table 12, the Economically Disadvantaged group had no girls who met this standard and $18 \%$ of the Not Economically Disadvantaged group of girls met the standard. Concerning the 2016-2017 school year, a statistically significant difference was revealed, $\chi^{2}(1)=24.10, p<.001$, moderate effect size, Cramer's V of, .33 (Cohen, 1988). As delineated in Table 12, The Economically Disadvantaged group had 27.83 times fewer girls who met this standard than the Not Economically Disadvantaged group of girls. Concerning the 2017-2018 school year, the result was statistically significant, $\chi^{2}(1)=7.31, p=.007$, small effect size, Cramer's V of .21 (Cohen, 1988). The 
Economically Disadvantaged group, as revealed in Table 12, had 6.82 times fewer girls who met this standard than the Not Economically Disadvantaged group of girls.

Table 12. Frequencies and Percentages for the STAAR Reading Phase-in 3 Standard by the Economic Status of Grade 4 Girls in Special Education for the 2014-2015 School Year through the 2017-2018 School Year

\begin{tabular}{lcccc}
\hline & \multicolumn{2}{c}{ Met Standard } & \multicolumn{2}{c}{ Did Not Meet Standard } \\
\cline { 2 - 5 } School Year and Economic Status & $\boldsymbol{n}$ & $\boldsymbol{\%}$ & $\boldsymbol{n}$ & $\boldsymbol{\%}$ \\
\hline 2014-2015 & 7 & 8.80 & 73 & 91.30 \\
$\quad$ Not Economically Disadvantaged & 2 & 1.20 & 161 & 98.80 \\
$\quad$ Economically Disadvantaged & & & & \\
2015-2016 & 9 & 18.00 & 41 & 82.00 \\
$\quad$ Not Economically Disadvantaged & 0 & 0.00 & 94 & 100.00 \\
$\quad$ Economically Disadvantaged & & & & \\
2016-2017 & 10 & 16.70 & 50 & 83.30 \\
$\quad$ Not Economically Disadvantaged & 1 & 0.60 & 162 & 99.40 \\
$\quad$ Economically Disadvantaged & & & & \\
2017-2018 & 5 & 11.60 & 38 & 88.40 \\
$\quad$ Not Economically Disadvantaged & 2 & 1.70 & 114 & 98.30 \\
$\quad$ Economically Disadvantaged & & &
\end{tabular}

In this multi-year investigation, the reading performance of Grade 4 boys and girls in special education was examined as a function of their economic status. Reading performance consisted of two different sets of measures: (a) several test questions answered correctly and (b) percentages of students who met three reading standards. Inferential statistical analyses revealed the presence of statistically significant differences in all of the reading performance measures of Grade 4 boys by their economic status. Results were different for girls in that statistically significant differences occurred infrequently in the number of test questions answered correctly but in all of the percentage measures. Results will now be discussed separately for boys and girls.

In each STAAR Reading Reporting Category and all four years investigated, boys in the Economically Disadvantaged group had statistically significantly lower reading scores than boys in the Not Economically Disadvantaged group. In addition, the same trends were present in all four years concerning the STAAR Reading Phase-in 1, 2, and 3 Standards by student economic status in that lower percentages of boys in the Economically Disadvantaged group met this standard than boys in the Not Economically Disadvantaged group.

In examining the reading performance of Grade 4 girls in Texas across the four years of data that were analyzed herein, few statistically significant results were present for the STAAR Reading Reporting Categories. In the majority of these analyses, regardless of their economic status, girls answered a similar number of items correctly on the STAAR Reading Reporting Categories. In contrast, consistent trends in scores were present by student economic status for the STAAR Reading Phase-in 1, 2, and 3 Standards. For each of the STAAR Reading Phase-in 1, 2, and 3 
Standards, and in all four years investigated, girls in the Economically Disadvantaged Group had statistically significantly lower percentages who met this standard than girls in the Not Economically Disadvantaged group.

As revealed in this study, boys and girls in special education who also live in poverty had statistically significantly lower reading test scores than boys and girls who live in more advantaged circumstances. These findings are commensurate with the results of other researchers (Harris, 2018; Harris \& Slate, 2017; McGown, 2016; Schleeter, 2017) who documented the presence of substantial achievements gaps as a function of special education enrollment status, gender, and poverty. Furthermore, the research results delineated herein were congruent with national educational reform legislation in that substantial disparity gaps continue to deny students a free and appropriate public education that is commensurate with their mainstream peers (American Psychological Association, 2012; Ravitch, 2013). Childhood poverty continues to impact negatively the ability of children to learn and read (e.g., Harris, 2018; Harris \& Slate, 2017; Hernandez, 2012; McGown, 2016; Reardon, 2011; Wright \& Slate, 2015). Prior researchers (e.g., Jones et al., 2017) revealed that students in special education tend to struggle with reading at greater rates than those in mainstream education, which was further supported by this research.

Based upon the results of this multi-year statewide analysis, several implications for policy and practice can be made. First, action needs to be taken by educators and policymakers to provide funding and resources to address the reading performance imbalance that exists for students enrolled in special education who are also living in poverty. Specifically, additional funding could be used to provide support and resources to students in special education who have the greatest needs based on screening data. Second, results suggest that more financial resources should be provided to school districts to fund pre-kindergarten special education programs and to build foundational literacy skills in students through early intervention. Third, Grade 3 STAAR Reading results should be used to create differentiated instructional interventions for Grade 4 boys and girls in special education to respond to reading gaps immediately. Fourth, educator professional development should include strategies for teaching literacy to students with disabilities that could help teachers who may be unaware of the instructional needs of the special education student population.

\section{Conclusion}

The purpose of this research study was to determine the extent to which differences were present in the reading performance of Texas Grade 4 boys and girls as a function of their economic status (i.e., Economically Disadvantaged and Not Economically Disadvantaged). Through inferential statistical analyses of four years of Texas statewide data, statistically, significant differences were revealed in the reading performance of boys in all four years in all Reading Reporting Categories I, II, and III and STAAR Reading Phase-in 1, 2, and 3 standards. Specifically, boys in the Economically Disadvantaged group had lower reading skills than boys in the Not Economically Disadvantaged group. 
In examining the reading performance of Grade 4 girls in Texas across the four years of data, few statistically significant results were present. Regardless of their economic status, girls answered a similar number of items correctly on the STAAR Reading Reporting Categories. In contrast, consistent trends in scores were present by student economic status for the STAAR Reading Phase-in 1, 2, and 3 Standards. For each of the STAAR Reading Phase-in 1, 2, and 3 Standards, and in all four years investigated, girls in the Economically Disadvantaged Group had statistically significantly lower percentages of girls who met this standard than girls in the Not Economically Disadvantaged group. Pertaining to the substantial reading imbalance for students living in poverty, findings of this multiyear statewide investigation were consistent with prior researchers (American Psychological Association, 2012; Harris, 2018; Harris \& Slate, 2017; Hernandez, 2012; Jones et al., 2017; McGown, 2016; Ravitch, 2013; Reardon, 2011; Wright \& Slate, 2015).

Based upon the results of this multiyear investigation, several suggestions can be made for future research. First, researchers should determine if similar gaps in reading performance are evident based on ethnicity/race for boys and girls in special education. In this study, only economic status was examined. However, other demographic factors may contribute to reading performance for boys and girls in special education. Second, researchers should also examine the degree to which English Language Learner status is related to the reading performance of boys and girls in special education. As in the first recommendation, only the connection between economic status and reading performance in this study but other demographic analyses may provide additional insights. Third, researchers should replicate this study in other states. This investigation only included students in the State of Texas. Fourth, researchers should examine the connections between other content areas such as mathematics, social studies, and science. The focus of this study was only on reading performance. Fifth, researchers should determine whether differences are present for boys and girls in special education in other grade levels. Data on only boys and girls in Grade 4 were examined in this study.

\section{References}

American Psychological Association, Presidential Task Force on Educational Disparities. (2012). Ethnic and racial disparities in education: Psychology's contributions to understand and reducing disparities. Retrieved from https://www.apa.org/ed/resources/racial-disparities.

Burney, V. H., \& Beilke, J. R. (2008). The constraints of poverty on high achievement. Journal for the Education of the Gifted, 31, 171-197.

Carpenter, D., Ramirez, A., \& Severn, L. (2006). Gaps or gaps: Challenging the singular definition of the achievement gap. Education and Urban Society, 39(1), 113-127.

Cohen, J. (1988). Statistical power analysis for the behavioral sciences (2nd ed.). Hillsdale, NJ: Lawrence Erlbaum.

Creswell, J. W., \& Creswell, J. D. (2018). Research design: Qualitative, quantitative, and mixed methods approaches (5th ed.). Thousand Oaks, CA: Sage.

Field, A. (2009). Discovering statistics using SPSS (3rd ed.). Thousand Oaks, CA: Sage. 
Harris, L. V. (2018). Differences in the reading performance of Texas Grade 4 students as a function of their economic status, gender, and ethnicity/race: A multiyear, statewide investigation. Doctoral Dissertation, Sam Houston State University, Huntsville, TX.

Harris, L. V., \& Slate, J. R. (2017). Differences in reading by the economic status of Grade 3 Black boys and girls. Annal of Language and Literature, 1(2), 20-27.

Hernandez, D. J. (2012). Double jeopardy: How third-grade reading skills and poverty influence high school graduation. Baltimore, MD: Annie E. Casey Foundation.

Johnson, R. B., \& Christensen, L. (2017). Educational research: Quantitative, qualitative, and mixed methods approaches (6th ed.). Thousand Oaks, CA: Sage.

Jones, G., Ostojic, D., Menard, J., Picard, E., \& Miller, C. J. (2017). Primary prevention of reading failure: Effect of universal peer tutoring at early grades. Journal of Edecuational Research, 110(2), 171-176. http://dx.doi.org/10/1080/00220671.2015.1060929.

Lee, K. M., \& Slate, J. R. (2014). Differences in advanced achievement outcomes for Texas students as a function of economic disadvanatge. Journal of Education Research, 8(3), 137149.

McGown, J. A. (2016). Differences in reading performance of Texas elementary school students as a function of their economic status, gender, and ethnicity/race: A multiyear statewide study. Doctoral Dissertation, Sam Houston State University, Huntsville, TX.

National Center for Education Statistics. (2019a). Children and Youth with Disabilities. Retrieved from https://nces.ed.gov/programs/coe/indicator_cgg.asp.

National Center for Education Statistics. (2019b). Fast Facts: Title 1. Retrieved from https://nces.ed.gov/fastfacts/display.asp?id=158.

National Center for Children in Poverty. (2019). Texas demographics of poor children. Retrieved from http://www.nccp.org/profiles/TX_profile_7.html.

Ravitch, D. (2013). Reign of error: The hoax of the privatization movement and the danger to American's public schools. New York: NY: Knopf.

Reardon, S. F. (2011). The widening academic achievement gap between the rich and the poor. New evidence and possible explanations. In G. J. Duncan \& R. J. Murnane (Eds.), Whither opportunity? Rising inequality, schools, and children's life chances (pp. 91-116). New York, NY: Russell Sage Foundation.

Schleeter, G. (2017). Differences in the reading achievement of Texas Grade 3 English Language Learners as a function of their economic status, ethnicity/race, and gender: A multiyear statewide study (Doctoral dissertation).

Texas Education Agency. (2011). STAAR Grade 4 Reading Assessment: Eligible Texas Essential Knowledge and Skills. Austin, TX: Author. Retrieved from https://tea.texas.gov/WorkArea/DownloadAsset.aspx?id=2147488114.

Texas Education Agency. (2018c). Enrollment in Texas Public Schools 2017-18. Austin, TX: Author.

United States Department of Agriculture. (2017). The cost of raising a child. Retrieved from https://www.usda.gov/media/blog/2017/01/13/cost-raising-child. 
Differences in Reading by the Economic Status of Texas Grade 4 Boys and Girls

in Special Education: A Multiyear Statewide Investigation

United States Department of Health and Human Services. (2019). Poverty guidelines. Retrieved from https://aspe.hhs.gov/poverty-guidelines.

Wright, L. A., \& Slate, J. R. (2015). Differences in critical thinking skills for Texas middle school students as a function of economic disadvantage. Journal of Education Research, 9(4), 345356. 